\title{
Optimization of living conditions for seedlings of flowering shrubs
}

\author{
Marina Dogadina ${ }^{1 *}$, Maxim Larionov ${ }^{2}$, Peter Pravdyuk $^{l}$ and Alexander Pravdyuk ${ }^{3}$ \\ ${ }^{1}$ Federal State Budgetary Educational Institution of Higher Education «Orel State Agrarian University \\ named after N.V. Parakhin», 69, Generala Rodina St., 69, Orel, 302019, Russia \\ ${ }^{2}$ Federal State Budgetary Educational Institution of Higher Education «Saratov National Research \\ State University named after N. G. Chernyshevsky», 83, Astrakhanskaya Str., Saratov, 410012, Russia \\ ${ }^{3}$ Federal State Budgetary Educational Institution of Higher Education «Orel State University named \\ after I. S. Turgenev», 95, Komsomolskaya st., Orel, 302026, Russia
}

\begin{abstract}
A strategically important task of nursery in the modern realities of urban development, perspectivization and greening of landscape design of urban ecosystems, is the cultivation of high-quality planting material of ornamental crops in an optimally short time. Researches on improving seedling production technology have actual and practical importance in solving these problems. Scientifically-based measures, including optimization of soil conditions by applying vermicompost obtained from sewage sludge, buckwheat husk and ash using earthworms from the family Lumbricidae, in combination with buckwheat husk ash, as well as treatment with immunomodulating bioactive substances "Mival-agro", "Gumi", "Lignohumate", allowed to increase plant survival, improve biometric indicators and obtain seedlings of the 1 st commercial grade with the possibility of using them for special landings (solitaire, mixborder).
\end{abstract}

\section{Introduction}

Creating a favorable microclimate in the environment of a modern city is an urgent and popular direction [1,2]. The role of ornamental plants in stabilizing and improving the environmental situation in megacities is undeniable. They create a natural favorable healing framework that has the functions of sanitation, phytoncidal activity, dust, gas, noise and sound absorption. One of the most important features of landscape design of the territory is the formation of a decorative complex that creates aesthetic appeal, beneficial psychoemotional effects on the human body [3-7]. The leading place in landscape complexes belongs to flowering shrubs that give a special style to the design of the territory; they characterized by abundant, long-lasting flowering [8-10]. However, the environment of the city is extremely aggressive for plants. The impact of a complex of abiotic and biotic factors leads to a decrease in decorative properties, often the death of plants [11-13]. The selection of the assortment requires an integrated approach based on the formation of high-quality,

\footnotetext{
*marinadogadina@yandex.ru
} 
healthy planting material, in order to maximize the potential of ornamental plants adapted to growing conditions of the particular area $[14,15]$.

The purpose of the study is to optimize the growing conditions of flowering shrubs using a nutrient substrate and bioactive substances. The objectives of the study were to evaluate the influence of the nutrient substrate and bioactive substances on the acclimatization rate of ornamental plant and their biometrics.

\section{Materials and methods}

The research was conducted in the nursery of the municipal unitary enterprise of the Orel city in 2017-2019. Objects of research: dwarf ninebark (Physocarpus opulifolius L.), Ural false spiraea (Sorbaria sorbifolia L.), common lilac (Syringa vulgaris L.), Spiraea Bumalda (Spiraea bumalda Burv.), English dogwood (Philadelphia coronarius L.). As non-traditional fertilizers were applicated vermicompost obtained on the basis of sewage sludge, buckwheat husk and ash using earthworms from the family Lumbricidae, buckwheat husk ash LLC "Elite" (Orel). Plot area is $10 \mathrm{~m}^{2}$, three replications of experiment, randomized placement.

Experiment variants: 1 . Vermicompost $\left(6 \mathrm{~kg} / \mathrm{m}^{2}\right)+$ Ash $\left(100 \mathrm{~g} / \mathrm{m}^{2}\right)+$ "Mival-agro", $95 \%$ k.r.p. (10 g/ha) (processing of planting material) + "Gumi", 0.1\% (0.4 1/ha) + "Lignohumate", $0.1 \%(0.5 \mathrm{l} / \mathrm{ha}) ; 2$. Control. Yearlings were planted in the prepared substrate, previously the root system of plants was immersed in a solution of the biostimulator "Mival-Agro" for 24 hours. Soil dressing with biological fertilizers was carried out three times with an interval of 3 weeks; spraying with an immunomodulator "Mival-Agro" was conducted 4 weeks after planting three times with an interval of 3 weeks. In the control variant, the plants were treated with water.

According to the current standards for seedlings of ornamental shrubs grown in nurseries and intended for urban greening, following indices were taken into account to determine the commercial grade of the resulting seedling: the intensity of shoots growth, the number of main shoots, the length of the root system.

The growth dynamics of the root system, the shoots growth of flowering shrubs seedlings; the number of main shoots were studied. Measuring the length of the root system was performed from the root neck to the lower point of the cut vertically. The appearance of seedlings, the presence of external signs of damage by pests and diseases, as well as mechanical damage were determined visually.

\section{Results and discussion}

The efficacy of the nutrient substrate (vermicompost + ash) was evaluated by the acclimatization rate of rooted cuttings, the difference in the shoots growth, the number of shoots, and the timing of flowering plants.

The acclimatization rate in the experimental variant was $100 \%$, which is more by $1.2-1.3$ times than in comparison with the control, on average for plant species.

One of the priorities in nursery, which is of economic importance, is the supply to the market of well-formed plants adapted to growing conditions in the shortest possible time. The integrated complex, which includes an environmentally safe nutrient substrate, a number of bioactive fertilizers and immunomodulators, was allowed to obtain high-quality seedlings, which is important and promising in nursery. The created favorable conditions had a positive effect on the growth rate of seedlings of flowering shrubs (Fig. 1-5). 


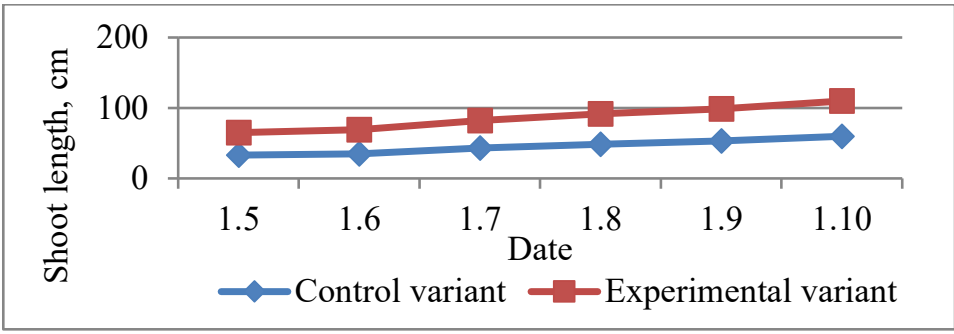

Fig. 1. Influence of fertilizers and BAS on the growth rate of shoots Physocarpus opulifolius L.

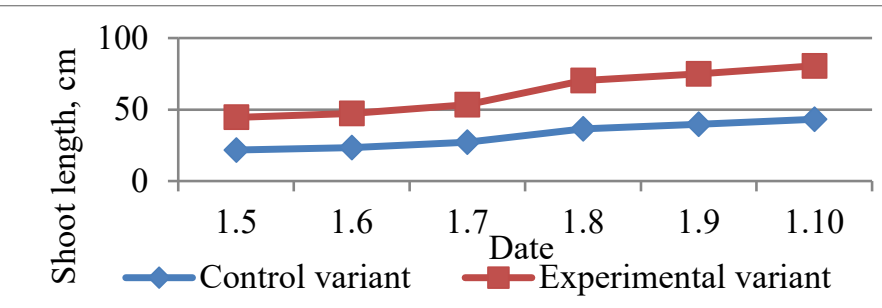

Fig. 2. Influence of fertilizers and BAS on the growth rate of shoots Sorbaria sorbifolia L.

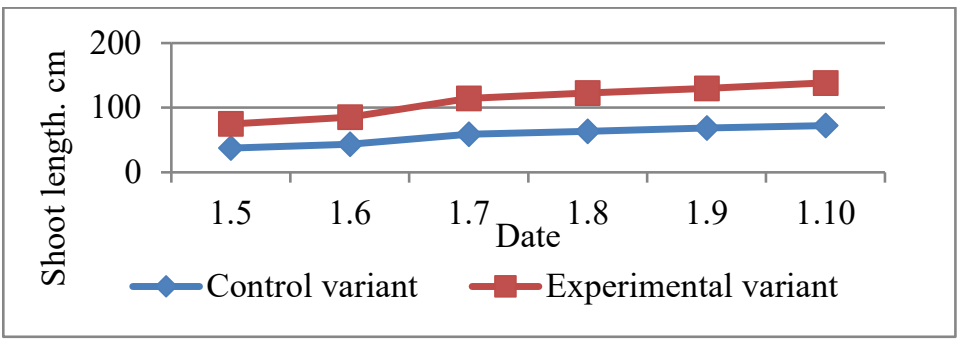

Fig. 3. Influence of fertilizers and BAS on the growth rate of shoots Syringa vulgaris L.

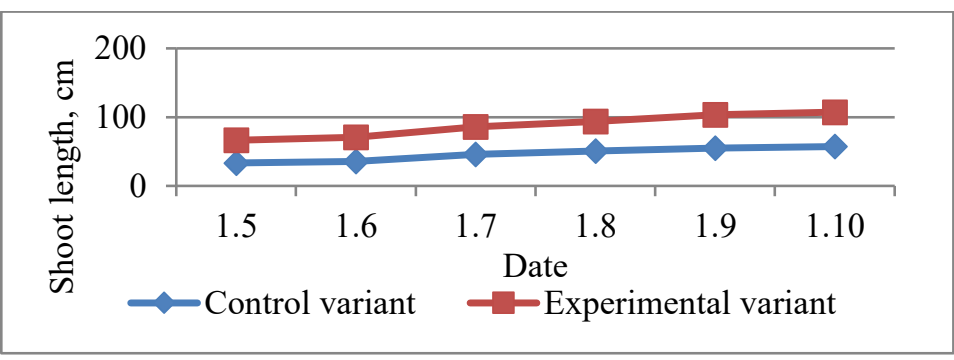

Fig. 4. Influence of fertilizers and BAS on the growth rate of shoots Spiraea bumalda Burv.

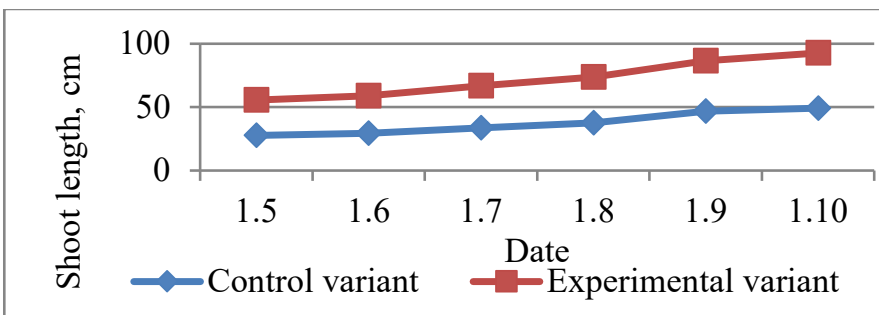

Fig. 5. Influence of fertilizers and BAS on the growth rate of shoots Philadelphus coronarius L. 
According to the conducted research, the fertilizer mixture introduced into the soil, including vermicompost and ash, as well as the integration of this method with the application of bioactive substances before planting and during vegetation, had a positive effect on the shoots growth rate of flowering shrubs. In comparison with the control variant plants of the experimental variant developed more intensively, in general, the shoots growth of Physocarpus opulifolius L. was $26.7 \mathrm{~cm}$, Sorbaria sorbifolia L. $-21.5 \mathrm{~cm}$, Syringa vulgaris L. $-34.8 \mathrm{~cm}$, Spiraea bumalda Burv. $-23.8 \mathrm{~cm}$, Philadelphus coronarius L. $-21.5 \mathrm{~cm}$, which is more than 1.5 times in contrast to control plants for Physocarpus opulifolius L. and Sorbaria sorbifolia L., 1.2 times for Syringa vulgaris L., 1.4 times for Spiraea bumalda Burv. and Philadelphia coronarius L.

Table 1. Influence of fertilizers and BAS on biometric indicators of flowering shrubs.

\begin{tabular}{|c|c|c|c|c|}
\hline $\begin{array}{l}\text { Experiment } \\
\text { variants }\end{array}$ & Species & $\begin{array}{l}\text { Number of } \\
\text { main } \\
\text { shoots, pcs. }\end{array}$ & $\begin{array}{l}\text { Root } \\
\text { system } \\
\text { length, cm } \\
\end{array}$ & $\begin{array}{l}\text { Percentage } \\
\text { of flowering } \\
\text { plants, } \%\end{array}$ \\
\hline \multirow{5}{*}{$\begin{array}{l}\text { 1.The } \\
\text { experimental } \\
\text { variant }\end{array}$} & Physocarpus opulifolius L. & 7.8 & 33.8 & 0 \\
\hline & Sorbaria sorbifolia L. & 5.8 & 26.9 & 9 \\
\hline & Syringa vulgaris L. & 4.3 & 30.1 & 100 \\
\hline & Spiraea bumalda Burv. & 9.1 & 26.2 & 100 \\
\hline & Philadelphus coronarius L. & 8.6 & 43.1 & 55 \\
\hline \multirow{5}{*}{$\begin{array}{l}\text { 2.Control } \\
\text { variant }\end{array}$} & Physocarpus opulifolius L. & 4.3 & 25.8 & 0 \\
\hline & Sorbaria sorbifolia L. & 3.1 & 23.7 & 0 \\
\hline & Syringa vulgaris L. & 2.8 & 20.3 & 21 \\
\hline & Spiraea bumalda Burv. & 5.2 & 22.1 & 38 \\
\hline & Philadelphus coronarius L. & 4.3 & 25.3 & 17 \\
\hline
\end{tabular}

The applied complex of fertilizers and bioactive substances had a high positive effect in increasing the number of main shoots of flowering shrubs seedlings, the length of the root system of plants. The greatest responsiveness was observed in plants of Philadelphia coronarius L., the number of main shoots increased by 2 times, the length of the root system by 1.7 times; the number of main shoots increased by 1.8 times in plants of Physocarpus opulifolius L., Sorbaria sorbifolia L., Spiraea bumalda Burv. One of the disadvantages of flowering shrubs seedlings is their flowering on 3-4 year (Physocarpus opulifolius L., Sorbaria sorbifolia L. on 4-5 years). Seedlings of Syringa vulgaris L. and Spiraea bumalda Burv., grown in experimental variants, bloomed in the 2nd year.

On the seedlings of flowering shrubs no mechanical damage was noted, as well as signs of damage by diseases and pests.

All seedlings obtained with the complex application of vermicompost, ash, "MivalAgro", "Gumi" and "Lignohumate", according to GOST 26869-86 "seedlings of ornamental shrubs" were assigned to the 1 st commercial grade with the possibility of using for special plantings (solitaire, mixborder), seedlings of the control variant - to the 2 nd commercial grade with the purpose for mass planting.

\section{Conclusion}

Introduction of vermicompost in a dose of $6 \mathrm{~kg} / \mathrm{m}^{2}$ and ash $\left(100 \mathrm{~g} / \mathrm{m}^{2}\right)$ into the soil of the experimental plot, immersion of plant roots in the solution of the biostimulator "MivalAgro", soil dressing with biological fertilizers ("Gumi", "Lignohumate") during the growing season allowed optimizing the life support conditions of flowering shrubs seedlings. The acclimatization rate of seedlings in the experimental variant was $100 \%$; the growth of shoots of Physocarpus opulifolius L. was $26.7 \mathrm{~cm}$, Sorbaria sorbifolia L. $21.5 \mathrm{~cm}$, Syringa vulgaris 
L. $34.8 \mathrm{~cm}$, Spiraea bumalda Burv. $23.8 \mathrm{~cm}$, Philadelphus coronarius L. $21.5 \mathrm{~cm}$, which is more than 1.5 times in contrast to control plants for Physocarpus opulifolius L. and Sorbaria sorbifolia L., 1.2 times for Syringa vulgaris L., 1.4 times for Spiraea bumalda Burv. and Philadelphia coronarius L.: seedlings of 1 commercial grade were obtained.

\section{References}

1. L. Barrico, H. Castro, A. Pereira Coutinho, M. Teresa Gonçalves, P. Castro, Urban For. Urban Green., 29, 19-27 (2018). https://doi.org/10.1016/j.ufug.2017.10.012

2. J. E. A. Gomez Jr., Progress in Planning, 116, 1-29 (2017). https://doi.org/10.1016/j.progress.2016.03.001

3. G. C. Ciftcioglu, S. Ebedi, K. Abak, Ecol. Indic., 102, 278-288 (2019). https://doi.org/10.1016/j.ecolind.2019.02.048

4. S. Rahnema, S. Sedaghathoor, M. S. Allahyari, C. A. Damalas, H. E. Bilali, Urban For. Urban Green., 39, 98-108 (2019). https://doi.org/10.1016/j.ufug.2018.12.007

5. Y. Ren, Y. Ge, D. Ma, X. Song, Y. Shi, K. Pan, Z. Qu, P. Guo, W. Han, J. Chang, Urban For. Urban Green., 27, 305-313 (2017). https://doi.org/10.1016/j.ufug.2017.08.011

6. J. M. Maya Manzano, R. Tormo Molina, S. Fernández Rodríguez, I. Silva Palacios, Á. Gonzalo Garijo, Landsc. Urban Plan., 157, 434-446 (2017). https://doi.org/10.1016/j.landurbplan.2016.08.011

7. N. Hanita Nik Mohamad, S. Idilfitri, S. Khalizah Syed Othman Thani, Procedia - Social $\begin{array}{llll}\text { and Behavioral } & \text { Sciences, } & \text { 1053, } 2013) \text {. }\end{array}$ https://doi.org/10.1016/j.sbspro.2013.11.085

8. E. Łaszkiewicz, D. Sikorska, Environ. Sci. Policy, 110, 1-13, (2020). https://doi.org/10.1016/j.envsci.2020.05.009

9. K.J.H. Williams, K.E. Lee, L. Sargent, K.A. Johnson, J. Rayner, C. Farell, R.E. Miller, N.S.G. Williams, Urban For. Urban Green., 44, 126-139 (2019). https://doi.org/10.1016/j.ufug.2019.126399

10. K. Vierikko, P. Gonçalves, D. Haase, B. Elands, C. Ioja, M. Jaatsi, M. Pieniniemi, J. Lingren, F. Grilo, M. Santos-Reis, J. Niemelä, V. Yli-Pelkonen, Urban For. Urban Green., 48, 126501 (2020) https://doi.org/10.1016/j.ufug.2019.126501

11. K. L. Neil, L. Landrum, J. Wu, J. Arid Environ., 74(4), 440-444 (2010). https://doi.org/10.1016/j.jaridenv.2009.10.010

12. S. Świerszcz, A. Nowak, P. Kojs, S. Nowak, M. Nobis, Urban For. Urban Green., 41, 323-322 (2019). https://doi.org/10.1016/j.ufug.2019.05.001

13. L. Deng, X. Li, H. Luo, E. Fu, J. Man, L. Sun, Z. Huang, S. Cai, Y. Jia, Urban For. Urban Green., 48, 126488 (2020) https://doi.org/10.1016/j.ufug.2019.126488

14. M. Radhakrishnan, I. Kenzhegulova, M.G. Eloffy, W.A. Ibrahim, C. Zevenbergen,

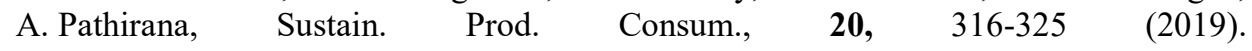
https://doi.org/10.1016/j.spc.2019.08.004

15. S. Volis, Plant Diver., 38(1), 45-52 (2016). https://doi.org/10.1016/j.pld.2016.05.003 